\title{
Orthographic Similarity Effects of Kanji on Japanese Education Students' Cognition
}

\author{
Mintarsih \\ Universitas Negeri Surabaya \\ Surabaya, Indonesia \\ Mintarsih@unesa.ac.id \\ Subandi \\ Universitas Negeri Surabaya \\ Surabaya, Indonesia \\ Subandi@unesa.ac.id
}

\author{
Bambang Yulianto \\ Universitas Negeri Surabaya \\ Surabaya, Indonesia \\ bambangyulianto@unesa.ac.id
}

\author{
Didik Nurhadi \\ Universitas Negeri Surabaya \\ Surabaya, Indonesia \\ DidikNrhadi@unesa.ac.id
}

\begin{abstract}
- the current study explores the similarity effect of kanji orthographic to 53 studentsat Japanese education departmentwhile reading and writing kanji. This research employed qualitative method and error analysis technique. Kanji studied is a combined kanji of 2 kanji (nijijukugo). The similarity effect of graphical kanji to reading and writing errors is classified into 2 categories, (1) misspelling of target kanji which then affect meaning, (2) non-kanji errors type. This study indicates that effect of orthographic similarity on process of understanding kanji on cognition of learners involves various information contained in kanji i.e. graffiti, radical, kanji component, pronunciation, and meaning relationships. Existence of this relationship proves it is also important to conduct research from effects of phonological, morphological, or semantic point of kanji lexical. This research has implications for kanji teaching materials within more attention to effect of similarity between kanji, especially when individual kanji formsmanycombined kanji of 2 kanji or more called jukugo.
\end{abstract}

Keywords—effects, orthographic similarity, niji jukugo, reading of kanji )

\section{INTRODUCTION}

As the number of identifiable individual kanji increases, more words will also be formed from combined kanji. However, similarity effect of kanji visual form is often one of obstacles affecting learning of kanji. Therefore, this study tries to identify, analyze, and describe how kanji visual similarity effect to learners' recognition.

The recognition of kanji as letters, words, and symbol in Japanese activates information such as graphics, pronunciation, or kanji meaning that takes place interactively in the minds of learners. This activation process occurs because of a visual stimulus kanji graphical configuration in writing. Kanji processing is not essentially the same as kana or alphabet processing, especially in the early stages of processing. There is a difference in the pattern recognition process of the logographic type. Logographic stimuli typically display greater dependence on the various graphic features found in visual stimuli. The kanji processing is influenced by several factors, e.g. a given kanji contextual arrangement, specific features of the familiarity, frequency, and complexity of kanji [1].

\section{A. Kanji architectural design as orthographic}

The architectural design of kanji as a letter consists of bushu (radical) components, kakushuu (number of strokes in kanji writing), hitsujun (strokes order in kanji writing), rikusho (kanji origins) and how to read kanji (onyomiis Chinese pronunciation and kunyomiis Japanese pronunciation). In Japanese is known four types of script, i.e. kana letter consisting of hiragana and katakana, kanji, and romaji (Roman letters). Japanese characters are classified into hyoonmoji (phonogram) and hyoimoji (ideogram) [2]. The phonogram consists of alphabetical Roman letters andsyllabogram of kana, while the ideogram in the form of kanji, as shown in the following chart.

\section{FIGURE $1 . \quad$ JAPANESE CHARACTERS}

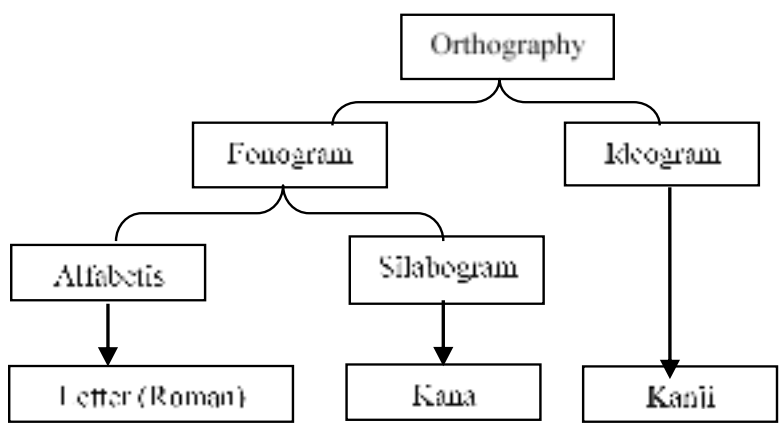


Hiragana and katakana itself each consist of five vowel sounds, forty syllable sounds, and one consonant. Then add some derivative sounds (e.g.dakuon は $/ \mathrm{ha} /$ is ば $/ \mathrm{ba} /$, handakuonis ぱ/pa/, and you-onare びや/bya/, ぴや/pya/). Yokosuka (2002) explains kanji has a characteristic which can function as a letter, sound marker of object being referred, and word. Unlike alphabet that is a letter marker sound, kanji symbolizes meaning as well as the sound. Each kanji can be a word because it kanji also called logogram/logograf'hyogomoji'. When placing kanji as a letter, kanji-forming elements such as bushu (kanji root), tenkaku (kanji character streak), senbun (line segment) need careful attention, since the mistake of writing kanji elements will result in kanji not being read or possibly forming other kanji characters that have similarities. In another context, a single kanji character can serve as a word'go', and in event of a merger of two or more kanji characters kanji serves as a combined kanji'jukugo'. Because it has such a character, then in general kanji can also be called a word [3].

Kanji has root position of kanji (bushu) i.ehen, tsukuri, kanmuri, ashi, tare, nyoo, and kamae, bushu or radical consists of two types of phonetic radicals and semantic radicals; the procedure of writing kanji through sequence of graffiti (kanji-forming line)and formation of kanji (rikusho). Fushimi, Ijuin, Patterson, and Tatsumi [4] explain many (but not all) kanji characters containing two components: semantic radicals that often (but not always) provide a clue to the meaning of kanji, phonetics radicals that often (but not always) provide a sound clue of kanji character. Saito, Inoue, and Nomura, Ito in Kess and Miyamoto [1] describe the views of the basic formations of rikusho being classified into four namely i.e shokeimoji (ideographic kanji) is a kanji formed from simplification of natural form, shijimoji(diagrammatic kanji) is a simplification of something abstract or a concept, $k a i-i$ moji (compound-semantic kanji) is a kanji derived from a composite of two previously created kanji that form a new meaning, keiseimoji (phonetic-semantic kanji) is a kanji which is a combination of two kanji that express meaning and speech. Shokeimoji and shijimoji percentage occupy the smallest number of joyokanji, the largest percentage proportion is kai-i moji, and the largest proportion of the number of kanji is keiseimoji which almost covers $80 \%$ of total joyokanji[1].

Kanji orthographic similarities can be seen from kanjiforming components, i.e. radical, graffiti, kanji components, e.g. in kanji 休 /kyu/ (rest) with 体 /tai/ /karada/ (body); 親 /oya/ (parents) with 新 /shin/ (new), 顔 /kao/ (face) with頭 /atama//to/ (head), etc.

\section{B. Phonological aspects of kanji}

Associated with kanji when viewed phonologically, kanji has an onyomi and kunyomi pronunciation, and spelling in kana writing. The number of pronunciations either onyomi or kunyomi on an individual kanji results inconsistent pronunciations in the combined kanji'jukugo'. Fushimi, Ijuin, Patterson, and Tatsumi [4] explain the following.

a. Consistentjukugo is made up of two kanji characters each character component of this type of kanji has one onyomi pronunciation without alternative of onyomi and kunyomi pronunciation. This is said to be consistent if every constituent character has identical pronunciation in all words containing that character in the same position, e.g.kanji 義/gi/ (consultation), 題/dai/ (title).

b. Inconsistent (a character of kanji that has many ways of pronunciation in all words containing the same character) jukugoconsists of two kanji characters at least one of two characters of kanji combined has an alternative pronunciation kunyomi. However, the correct pronunciation of kanji is onyomi, although kunyomi may be used in other combined kanji.Typical inconsistency jukugois said to be a typical inconsistency if every constituent is an inconsistent character but pronunciation of both characters is statistically typical. Atypical inconsistency jukugois classified as atypical inconsistencies if both characters have multiple pronunciationat a particular position and the pronunciation of one or both kanji is statistically atypical e.g. kanji 神 when pronounced onyomi sounds /shin/, /jin/, kunyomisounds /us/, /kan/. In corpus of 31,000 words, this kanji appears in first character in 86 composite kanji, and is pronounced /shin/ in 71 words of total number of occurrences of 86 words, e.g. 神 経 /shinkei/, pronunciation /shin/ for kanji 神 located in the first position is called a typical design, and for other pronunciations are /jin/, /us/, /kan/ classifiedas atypical [4].

c. Shibahara, Zorzi, Hill, Wydell, Butterworth [5] added inconsistent kunyomi consists of two kanji characters, this kanji pronunciation is kunyomi which each component have onyomi but used in other word. The whole word pronunciation is kunyomi, although the typical pronunciation of each character is onyomi instead of kunyomi.

\section{Kanji teaching materials in Japanese education department}

Kanji studied in Japanese education department of UniversitasNegeri Surabaya for basic level refers to compulsory textbooks in learning Japanese in universities. The instructional materials was conducted on textbooks of Japanese elementary level i.e.Minna no Nihongo vol.1-2 [6], basic kanji textbooksKanjivol. 1-2 [7], and basic reading bookDokkai vol. 1 [8].Counting of kanji was focused on the emergence of kanji in each chapter of textbook. The occurrence of kanji has been calculated in form of combined kanji, while in Kanji vol.1-2 in form of individual kanji. Purpose of this descriptionis to try to make a general overview, what kanji and how many kanji appear in each of early Japanese learning books. Description can be seen in following table. 
TABLE I. DESCRIPTIONOF LEARNING MATERIALS IN THE BASIC JAPANESE TEXTBOOK

\begin{tabular}{|c|c|c|}
\hline Textbooks & $\begin{array}{c}\text { Total number of } \\
\text { kanji composed of } 2 \\
\text { kanji }\end{array}$ & $\begin{array}{c}\text { Number of individual } \\
\text { simple and complex } \\
\text { kanji }\end{array}$ \\
\hline $\begin{array}{l}\text { Minna no Nihongo } \\
\text { Vol. } 1\end{array}$ & 524 & - \\
\hline $\begin{array}{l}\text { Minna no Nihongo } \\
\text { Vol. } 2\end{array}$ & 321 & - \\
\hline Kanji Vol. 1 & - & 221 \\
\hline Kanji Vol. 2 & - & 296 \\
\hline Dokkai Vol. 1 & 30 & - \\
\hline Total number & 875 & 518 \\
\hline
\end{tabular}

The number of combined kanji on Minna no Nihongo vol.1-2 is 845 , on Dokkai vol. 1 is 30 , with notes in this calculation there is no repeating of same combined kanji. This amount will be even more if kanji on combined kanji is counted as individual kanji. There are 875 composite kanji consisting of 2 kanji characters in Minna no Nihongo vol.1-2, and Dokkai vol.1, and 518 individual kanji on Kanjivol 1-2. So it can be said that standard of kanji mastery ability based on basic level of textbook is approaching an N3 JLPT standard i.e. $650 \mathrm{kanji}$, but the word mastery has not met an N3 level standard that is 3750 words. If predicting from 875 combined kanji on based level textbooks, vocabulary mastery is above N5 standard level of 800 words. In other words, the results of kanji teaching material computingin the basic Japanese textbooks for the students if referenced to Japanese language proficiency standard issued by The Japan Foundation can be said to approach N3 standard for mastery of kanji that is 518 of 650 kanji and above N5 standard for mastery of kanji is 875 of 800 words.

Mastery of kanji is very important in learning Japanese, because it can affect the fluency in reading, and smoothness is the foundation towards understanding. Pexman [9] states the general purpose of reading is to generate the meaning of the words of the text being read. Reading text involves a number of component processes, one of which is the recognition of the word visual. That is, the recognition of isolated words is assumed as one component of reading skill [9]. McClung, O'Donnell, and Cunningham quotes Ouellette, Treiman, Shahar-Yames [10] share most theories and research on the acquisition of orthographic knowledge emphasizes the importance of phonological encoding, some studies paying attention to its connection with the spelling process. It is a recurring act of linking oral and written form, through decoding or spelling, which helps to produce a good orthographic representation. This is a very important thing for reading skills.

\section{METHOD}
A. Participants
Participants in this study were 53 students in third semester in Japanese education departmentatUnesa in Surabaya.

Participants more or less studied about 700 combined kanji and 250 individual kanji.

\section{B. Instrument}

Instrument used in form of a written test consisting of 30 questions on kanji noyomikakikata (reading kanji as isolation word) and translate meaning, 10 questions on kanji no kakikata (writing kanji), and 5 questions on kanji noyomikata in a sentence. Participants wrote answers on answer sheets, the test lasts for 45 minutes. This tes was administered in class time.

\section{Data Analysis}

Data analysis technique was referring to three stages of error analysisthat were data collection, identification and error classification. And then, explain error by describing location of error, explaining the cause of error, and giving a correct example.

\section{RESULT AND DISCUSSION}

Research results of error analysis on reading and writing kanji can be classified on 2 category type of errorsi.e. A category was indicated that misspelling of target kanji due to similarity of kanji graphic form or one of kanji graphic forms of combined kanji, then affect a meaning of target kanji. B category was indicated the error of writing target kanji on the test of kanji no kakikata (writing of kanji) raising non-kanji errors. A meant by non-kanji errors is that letter is not a kanji even though it is written from parts of two kanji, as shown in following tables.

TABLE II. PARTICIPANT'S ERRORS ON READING AND WRITING KANJI

\begin{tabular}{|c|c|c|}
\hline \multicolumn{3}{|c|}{ Misspelling of target kanji (A Category) } \\
\hline Target kanji & $\begin{array}{l}\text { Partisipants } \\
\text { answer }\end{array}$ & Analysis \\
\hline 調子 /choushi/ & /shuuko/ & $\begin{array}{l}\text { Orthographic similarity effects } \\
\text { between kanji 調 /chou/ and 週 /shuu/ } \\
\text { on a phonetic radical called tsukuri. } \\
\text { But /shuuko/ has no meaning, because } \\
\text { /shuuko/ is a non-word }\end{array}$ \\
\hline 洗濯 /sentaku/ & /senyou/ & $\begin{array}{l}\text { Orthographic similarity effects } \\
\text { between kanji 濯 /taku/ and 曜 /you/ } \\
\text { on a phonetic radical called tsukuri. } \\
\text { But /senyou/ has no meaning, because } \\
\text { /senyou/ is a non-word }\end{array}$ \\
\hline 確認/kakunin/ & $\begin{array}{c}\text { /zasshi//zangy } \\
\text { ou/ }\end{array}$ & $\begin{array}{l}\text { Orthographic similarity effects } \\
\text { between kanji確認/kakunin/, 雑誌 } \\
\text { /zasshi/, 残業 /zangyou/ }\end{array}$ \\
\hline 転勤 /tenkin/ & /undou/ & $\begin{array}{l}\text { Orthographic similarity effects } \\
\text { between kanji 転勤/tenkin/ with kanji } \\
\text { 運動 /undou/, which is kanji 運 /un/ } \\
\text { looks similar to kanji 転/ten/ then on } \\
\text { kanji 動 /dou/ looks similar to kanji 勤 } \\
\text { /kin/, if note further kanji 動 /dou/ has } \\
\text { a similar combination between kanji 転 } \\
\text { /ten/ and 勤 /kin/ }\end{array}$ \\
\hline $\begin{array}{l}\text { 速達 } \\
\text { /sokutatsu/ }\end{array}$ & /en/ & $\begin{array}{l}\text { The sound of/en/ indicates a stopped } \\
\text { calling process when participant is } \\
\text { going to spell kanji 速達/sokutatsu/ } \\
\text { being /ensoku/ because one of kanji on }\end{array}$ \\
\hline
\end{tabular}




\begin{tabular}{|c|c|c|}
\hline \multicolumn{3}{|c|}{ Misspelling of target kanji (A Category) } \\
\hline & & $\begin{array}{l}\text { kanji 遠足 /ensoku/ has an } \\
\text { orthographic similarity with kanji 速 } \\
\text { /soku/, as shown速達/sokutatsu/ and } \\
\text { 遠足 /ensoku/. For more details, it is a } \\
\text { graphic similarity effects between kanji } \\
\text { 速 /soku/ and 遠 /en/, and the } \\
\text { similarity of kanji pronunciation /soku/ } \\
\text { but denoted by different graphic form } \\
\text { 速 /soku/ on 速達/sokutatsu/ with 足 } \\
\text { /soku/ on 遠足 /ensoku/ }\end{array}$ \\
\hline $\begin{array}{l}\text { 室/shitsu/ on } \\
\text { kanji 会議室 } \\
\text { /kaigishits/ }\end{array}$ & /ya/ & $\begin{array}{l}\text { orthographic similarityeffects between } \\
\text { kanji室 and 屋 that is an element kanji- } \\
\text { formers position under kanmuri on } \\
\text { kanji 室 /shitsu/ and tare on kanji 屋 } \\
\text { /ya/ }\end{array}$ \\
\hline $\begin{array}{l}\text { 料/ryou/ on } \\
\text { kanji 資料 } \\
\text { /shiryou/ }\end{array}$ & $/ \mathrm{ka} /$ & $\begin{array}{l}\text { orthographic similarities effects } \\
\text { between kanji 料 /ryou/ and科 /ka/. In } \\
\text { both kanji there are similarities in } \\
\text { phonetic radicals but differences in } \\
\text { semantic radicals. }\end{array}$ \\
\hline 段階 /dankai/ & /kaidan/ & $\begin{array}{l}\text { There are } 2 \text { kanji which have the same } \\
\text { graphic form and pronunciation but } \\
\text { different order as shown(1) 段 (2) 階 } \\
\text { /dankai/ and (2) 階 (1) 段 /kaidan/. }\end{array}$ \\
\hline \multicolumn{3}{|c|}{ Non-kanji writing's errors (B Category) } \\
\hline Targetkanji & $\begin{array}{c}\text { Partisipants } \\
\text { answer }\end{array}$ & Analysis \\
\hline さがす/sagasu/ & $\begin{array}{l}\text { Combine two } \\
\text { kanji which } \\
\text { have same } \\
\text { pronunciation } \\
\text { /sagasu/ there } \\
\text { were探す and } \\
\text { 捜すbecome } \\
\text { one kanji }\end{array}$ & Pronunciation similarity effects \\
\hline ねる/neru/ & $\begin{array}{l}\text { Combined two } \\
\text { kanji which } \\
\text { have } \\
\text { orthographic } \\
\text { similarity } \\
\text { there } \\
\text { were寝る/ner } \\
\text { u/ and 㷌る } \\
\text { /kaeru/become } \\
\text { one kanji }\end{array}$ & Orthographic similarity effect \\
\hline
\end{tabular}

The similarity effect of visual factors (orthographic) indicated as seen in example of data, that is kanji 転勤/tenkin/ spelled /undou/, /tenkou/occurs because of similarity between kanji 転勤 and kanji 運動. Kanji 運 /un/ has the same kanji component with kanji 転/ten/, as follows 運 $\rightarrow$ 転 and kanji 動 /dou/ appears as a composed component on kanji 転 + 勤 $\rightarrow$ 動 /dou/. Then it affects a meaning of kanji, as if there is a related meaning between /tenkin/ (work mutation), with /undou/ has been interpretedas motion, /tenkin/ has been interpretedas displacement. All of them have an equal in meaning that indicates movement; orthographic similarity between two kanji 室 and 屋 also affects reading of kanji. Kanji 室 on kanji 会議室/kaigishitsu/ should be read/shitsu/ but read /ya/; kanji 歌舞伎 /kabuki/ spelled 歌舞妓 /shimaiko/, kanji 舞 can be spelled /mai/ and /bu/, but in kanji
歌舞伎 /kabuki/ it should be spelled /bu/, the other participant's perception on kanji 歌舞伎 /kabuki/ is a similarity component between kanji 伎 / $\mathrm{ki} /$ and妓 / $\mathrm{ko} /$, two of kanji there are equally in phonetic radical but differences in semantic radical. Kanji 舞妓 /maiko/ has the similarity on meaning with geisha, but 歌舞妓/shimaiko/ has no meaning, because /shimaiko/ is a non-word; kanji 段階 /dankai/ and 階段 /kaidan/ is formed from 2 kanji which have exactly same kanji graphical form but different order as shown (1) 段 (2) 階 /dankai/ and (2) 階 (1) 段 /kaidan/. Similarity of kanji graphic form on both kanji affects kanji readings, whereas the two of kanji have very different meanings 段階 /dankai/ (level, class), 階段 /kaidan/ (ladder). Finally, all of data was classified in 2 types. Typeof misspelled error category is classified in part of A, and non-kanji errors in part of B.

The results of analysis can be said that in recognizing kanji, participants also need to pay attention to similarity of kanji graphic apart from pronunciation. Cunningham, Perry, \& Stanovich in McClung, O'Donnell, and Cunningham [10] state not only phonological abilities that influence development of speech recognition skills, but comprehensive reading models also need to reflect on role of other components orthographic processing, because at the time of reading individual processes and encodes certain sequence of letters in writing. Although the theorists differ in the notes of skillful reading, but all emphasize the fact that word recognition effectively requires a substantial supply of orthographic representations closely linked to semantics and phonological information. In addition, these experts suggest that weakness in ability to obtain detail, print-specific, and knowledge of words can lead to reading difficulties. Thus, developing a general understanding of how orthographic representations are obtained and how later to support word recognition is a necessary part of reading study [10].

McClung, O'Donnell, and Cunningham [10] add orthographic processes defined as ability to form, store, and access orthographic representations, which (1) prioritize possible sequence of letters in the orthographic field of language in question; and (2) are closely connected with phonological, semantic, morphological, and syntactical information in their language. That is, definition includes procedural aspect and the declaration of orthographic knowledge.

\section{CONCLUSION AND SUGGESTION}

This research provesthat orthographic similarity leads to false recognition of nijijukugo, with type of errorsi.e.misspelling and non-kanji. An inconsistent pronunciation on kanji also cause participants to misspell kanji. It gave rise to different onyomi readings (kanji reading with Chinese pronunciation)and then bring a new or wrong meaning in combine of two kanji. The relation of orthographic form, pronunciation, and meaning of kanjishow, besides the orthographic effect, it is also important to do research from phonological, morphological, or semantic lexical point of view of kanji. This study has implications for kanji teaching 
materials within more attention to the effect of similarity between kanji, especially when kanji studied is more numerous in form combined kanji (jukugo).

\section{REFERENCES}

[1] J.F. Kess, and T. Miyamoto, The Japanese Mental Lexicon: Psycholinguistic Studies of Kana and Kanji Processing. Amsterdam: John Benjamin Publishing Company, 1999.

[2] Y. Abe, and M. Nakamura, Moji Goi O Oshieru: Nihongo Kyojuho series 3. Tokyo: Hituzi Library, 2007.

[3] R. Yokosuka,"Goi oyobi Kanji Gakushu Sutorateji no Kenkyu," in Nihongo Kyoiku to Nihongo Gakushu: Gakushu Sutoratejiron ni mukete, S. Miyazaki, and J.V. Neustupny, Eds. Tokyo: Kurushio Shuppansha, 2002, pp. 97-116.

[4] T. Fushimi, M. Ijuin, K. Patterson, and I.F. Tatsumi, "Consistency, Frequency, and Lexicality Effects in Naming Japanese Kanji,” Journal of Experimental Psychology: Human Perception and Performance, Vol. 25, No. 2, 1999, pp.382-407.

[5] N. Shibahara, M. Zorzi, M.P. Hill, T. Wydell, and B. Butterworth, "Semantic Effects in Word Naming: Evidence from English and Japanese Kanji," the Quaterly Journal of Experiment Psychology, 56A (2), 2003, pp. 263-286.

[6] Y. Tanaka, et.al., Minna no Nihongo Vol. I\&II. Tokyo: 3A Corporation, 1999.

[7] K. Nishiguchi, et.al., Minna no Nihongo Vol I\&II: Kanji I\&II (English edition). Tokyo: 3A Corporation, 2001.

[8] A. Masano, et.al., Minna no Nihongo Vol I\&II: Shokyu de Yomeru topikku 25 Vol I\&II. Tokyo: 3A Corporation, 2001.

[9] P.M. Pexman, "Meaning-based Influences on Visual Word Recognition," inVisual Word Recognition, Vol. I: Models and Methods Orthograpy \& Phonologhy, J.S. Adelman, Eds. New York: Psychology Press, 2012, pp. 24-43.

[10] N.A. McClung, C.R. O’Donnell, and A.E. Cunningham, “Orthographic Learning and the Development of Visual Word Recognition," inVisual Word Recognition, Vol. I: Models and Methods Orthograpy \& Phonologhy,J.S. Adelman, Eds. New York: Psychology Press, 2012, pp.173-190 